\title{
A Glória de Jesus na Transfiguração e sua Contribuição para a formação da Cristologia Lucana: uma análise redacional de Lc 9,28-36
}

\author{
Orientador: Waldecir Gonzaga \\ Doutorando: Leonardo dos Santos Silveira \\ Área de Concentração: Teologia Bíblica \\ Linha de Pesquisa: Análise e Interpretação de Textos do Antigo e Novo Tes- \\ tamento
}

Projeto de Pesquisa: Análise dos livros bíblicos e extrabíblicos do Novo Testamento

A presente pesquisa tem como objetivo estudar o relato da Transfiguração no Evangelho de Lucas, na perícope 9,28-36. A Transfiguração Lucana possui uma redação muito distinta dos outros Evangelhos Sinóticos (Marcos e Mateus). Dentre as mudanças, está o termo $\delta$ ó $\xi \alpha$ (glória), que aparece duas vezes no relato (Lc 9,31.32). A primeira vez, para falar de Moisés e Elias e, a segunda, ao fazer menção de Jesus. Para a investigação do relato, parte-se do princípio que o pano de fundo para o mesmo encontra-se, sobretudo, na tradição angelomórfica e, que essa aproximação traz um auxílio significativo para o entendimento da Cristologia Lucana. Para tanto, em primeiro lugar, a pesquisa apresenta um Status Quaestiones acerca da Transfiguração. Depois, mediante os passos do Método Histórico-Crítico, a perícope de Lc 9,28-36 é analisada, dando destaque para a Análise Redacional. Em seguida, o entorno da Transfiguração Lucana é visto, a partir da abordagem dos seguintes tópicos: a Transfiguração em Marcos, a Transfiguração em Mateus, a tradição angelomórfica e deuses e homens divinos no mundo greco-romano. Após esse caminho, uma Cristologia da Transfiguração Lucana é explicitada e, através dela, a interação entre Lc 9,28-36 com o seu cenário judaico e a tradição an- 
gelomórfica. Por fim, através de outros desdobramentos redacionais, verifica-se a contribuição da Glória de Jesus no Evangelho como chave de leitura para a apresentação de Jesus em Lucas. Dentre os resultados alcançados pela pesquisa tem-se que o uso de $\delta$ ó $\xi \alpha$ (glória) deve ser lido por intermédio do aspecto místico dessa glória, que aponta para o Filho do Homem de Daniel. Igualmente, a caracterização de Jesus pode ser entendida como paradigma da angelização escatológica dos justos.

Palavras-chave: Transfiguração. Glória. Tradição angelomórfica. Evangelho de Lucas. Cristianismo primitivo. 